\title{
What Ifs and Multi-directional symptoms PBL cases: two simple and functional adjuncts to problem-based learning materials
}

\author{
Jeff Schwartz \\ Corresponding author: j.schwartz@griffith.edu.au \\ School of Medicine, Griffith University, Gold Coast QLD 4222, Australia
}

Keywords: problem-based learning, PBL, case-based learning, CBL, medical education

\begin{abstract}
Although problem-based learning (PBL) is widely used in medical education for its many virtues, a number of deficiencies exist. As means of enhancing the experience of PBL for students, two relatively simple adjuncts to PBL are presented. What Ifs are short hypothetical scenarios, appended to the end of a PBL case, that require students to revisit elements of the PBL case just completed and apply their newly acquired knowledge to clinical reasoning in an altered scenario or to explore anew another dimension of the PBL case. Multi-directional symptoms PBL cases are cases where a common presenting symptom, rather than a specific pathology, is the focus of the PBL case and, following a core narrative of the initial patient presentation, a series of independent continuation narratives with appropriate histories, examination findings and investigation results, lead students to divergent diagnoses and management issues. In addition to keeping the PBL process fresh by rotating new materials regularly, these adjuncts extend the PBL process in the direction of case-based learning.
\end{abstract}

Problem-based learning, PBL, as either the sole or core component of a curriculum in medical education, has numerous advantages over other modes of learning. These include experience in self-directed learning, allowance for the learning needs and styles of individual students, promotion of teamwork and group thinking and linking the learning of content (medical knowledge) to relevant clinical situations. In addition, in a well-integrated curriculum PBL itself can be amalgamated with clinical skills training and relevant social, community and public health issues woven into the PBL narrative.

In contrast, PBL has limited application in a number of other areas. Among the most important of these is a focus on problem-solving within the context of a single case, as opposed to acquiring and exercising generic clinical reasoning skills to a range of medical issues (Custers 2018; Shields 2011) within a structured approach (Thistlethwaite et al 2012; Srinivasan et al 2007). PBL is a busy process with multiple concurrent aims, including a requirement to learn the basic clinical knowledge in parallel with problem-solving. In addition, there is limited time available for students to dwell on the pathology at the core of one case before moving on to the next. Consequently, aside from listing differential diagnoses at various points in the discussion, it is usually difficult to pursue alternate lines of reasoning during the course of discussions in PBL cases (McLean, 2016). Related to this, and for good reason, is limiting the exposure of students, in general, to conventional presentations, replete with abundant symptoms and signs, of patients with common pathologies in the narratives of their PBL cases.

On one hand, restricting the subject matter of PBL cases to common presentations of common illnesses facilitates the learning of the scientific basis of the respective human system in health 
and disease. That is, since PBL is primarily a vehicle for learning content (remember, understand) - as opposed to application and analysis - the nucleus of the case is a medical condition to assist students' learning of anatomy, physiology, pathology, etc. Logically, the conditions are selected based on likelihood that students will encounter patients with these conditions, thereby increasing the value of with this particular knowledge in practice. On the other hand, it constrains the focus on the thought processes that would be involved in relating more real-life scenarios. Another shortcoming is that PBL cases typically focus on one core pathology at the expense of considering even relatively common co-morbidities, which often accompany and influence the core pathology. Again, this supports all the learning of content, but ignores opportunities to acquire practical knowledge in context.

An additional, important aspect of medicine that is most often omitted from PBL narratives is clinical judgment (Shields 2011). For example, at what pressure (and for what reasons) would a particular patient's hypertension indicate admitting a patient to hospital.

As PBL has matured its limitations have become apparent. A current stream of thought is that a hybrid model in which problem-based learning is enhanced by combining it with other learning modes confers learning synergies (Jiménez-Saiz \& Rosace 2019). Typically, hybrid PBL includes conventional lectures, but there is no reason to believe that hybridising a novel aspect of self-directed learning to PBL would not also result in enhanced learning.

Students often observe that PBL materials can be stale and uninteresting, a development which likely originates - at least partly - to the availability beforehand to PBL materials and resources from more senior students and other sources. One means of addressing the boredom associated with familiarity with the materials, without creating new PBL cases, is for the staff member present in the small group session to facilitate related clinical reasoning exercises, other clinically relevant discussions or peripheral discussions on subjects, such as ethical or public health implications of an item in the narrative. In addition to time constraints, the varied backgrounds of PBL facilitators/tutors, can limit the type and scope of peripheral discussion. Furthermore, unless prescribed, off-road discussions will inevitably vary among PBL groups, with the potential of creating wholly unequal experiences for each group of students.

\section{What Ifs}

In order to supplement and expand the overall experience in each PBL case with cues and directions for discussions that address some of the aforementioned deficiencies, we have created a renewable series of What Ifs to append to the end of PBL cases. What Ifs are very brief points of departure for further discussion and for adding another dimension of reasoning and thought to the learning in the narrative that preceded the release of the What Ifs. The placement of What Ifs at the end of PBL cases can shift the experience of the students more toward that of case-based learning (CBL) in that they can now use previously acquired knowledge to multiple clinical reasoning processes (ten Cate 2018), which they apply in novel situations (McLean 2016). The differences between PBL and CBL are neither universally accepted nor is a full discussion within the scope of this paper, but a few notes on the respective aims of PBL versus CBL will help to illustrate the value-adding of What Ifs. The following is a personal distillation of the literature into a single sentence. PBL is used as a vehicle for learning content and the small-group discussions are concerned with mutual learning by problem-solving and the facilitator, who is not a content expert, is largely passive, except to guide the process, whereas in CBL, students enter their small-group sessions having already learnt much of the content that will be the subject of discussion and they use the time in group 
to apply that knowledge across numerous practical scenarios with the active assistance of the content-expert facilitator (ten Cate 2018, McLean 2016, Custers 2018).

Although students are provided What Ifs at the end of the case, the What Ifs often revisit the thought processes which were conducted at various points in the PBL case by leading the students in an alternate reasoning direction. In addition, What Ifs can be used to exercise students' thinking in a broad variety of dimensions which would often be inefficient or counterproductive if pursued during the standard PBL process. Table 1 illustrates some of the dimensions added by What Ifs, along with any relevant learning objectives and an example to demonstrate the ways What Ifs can complement students' core learning.

\section{Table 1: Aspects of medical learning covered in What Ifs}

\begin{tabular}{|c|c|c|}
\hline dimension & learning objective & Example: What if... \\
\hline $\begin{array}{l}\text { Extended clinical } \\
\text { reasoning (may involve } \\
\text { secondary consequences) }\end{array}$ & $\begin{array}{l}\text { Apply principles of } \\
\text { clinical reasoning to } \\
\text { understand a medical } \\
\text { situation completely } \\
\text { and thereby anticipate } \\
\text { consequences }\end{array}$ & $\begin{array}{l}\text {... After her second myocardial } \\
\text { infarction, Mrs Lazarus develops a } \\
\text { systolic murmur in place of S1, } \\
\text { pulmonary oedema and a decreased } \\
\text { systolic blood pressure? What if it } \\
\text { happens acutely and includes a } \\
\text { holosystolic murmur directed to the } \\
\text { base of the heart? }\end{array}$ \\
\hline $\begin{array}{l}\text { Revisiting the } \\
\text { mechanisms of signs and } \\
\text { symptoms }\end{array}$ & $\begin{array}{l}\text { Understand the } \\
\text { underlying physiology } \\
\text { of the body systems } \\
\text { and relate changes in } \\
\text { function to signs and } \\
\text { symptoms of } \\
\text { pathology }\end{array}$ & $\begin{array}{l}\text {...Ms Sansbury has aortic stenosis, but } \\
\text { presents at medical outpatients not with } \\
\text { shortness of breath, but with having } \\
\text { experienced dizziness or fainting during } \\
\text { a vigorous set of tennis or after sitting in } \\
\text { a hot spa bath at the clubhouse after } \\
\text { golf; how would you explain the } \\
\text { symptoms? }\end{array}$ \\
\hline $\begin{array}{l}\text { Transition to patient } \\
\text { management }\end{array}$ & $\begin{array}{l}\text { Understand the } \\
\text { biological basis for } \\
\text { medical and surgical } \\
\text { treatment of } \\
\text { pathologies }\end{array}$ & $\begin{array}{l}\text {...Mrs Chesterton were ten years } \\
\text { younger or had healthier bones, would } \\
\text { there be other treatment options for the } \\
\text { fracture? }\end{array}$ \\
\hline $\begin{array}{l}\text { Extending or re- } \\
\text { examining basic science } \\
\text { issues and principles of } \\
\text { medicine }\end{array}$ & $\begin{array}{l}\text { Understand the } \\
\text { underlying physiology } \\
\text { of the body systems } \\
\text { and relate changes in } \\
\text { function to signs and } \\
\text { symptoms of } \\
\text { pathology; } \\
\text { other learning } \\
\text { objectives on specific } \\
\text { systems }\end{array}$ & $\begin{array}{l}\text {...a 24-year old man presents at a local } \\
\text { emergency department complaining of } \\
\text { palpitations, light-headedness and } \\
\text { anxiety. He says it happened once } \\
\text { before when he was exercising and } \\
\text { began feeling very tired and was a bit } \\
\text { short of breath (but he was, after all, } \\
\text { exercising at the time). The symptoms } \\
\text { went away so he did not pursue the } \\
\text { matter. When the palpitations and } \\
\text { anxiety started again at work today, he } \\
\text { stood up and felt dizzy or lightheaded. } \\
\text { He is having difficulty standing } \\
\text { unassisted. His heart rate is } 190 \text { and }\end{array}$ \\
\hline
\end{tabular}




\begin{tabular}{|c|c|c|}
\hline & & $\begin{array}{l}\text { seemingly regular. Thoughts? What to } \\
\text { do? }\end{array}$ \\
\hline $\begin{array}{l}\text { Cross-referencing } \\
\text { information (e.g. case } \\
\text { focuses on signs of a } \\
\text { pathology and the What If } \\
\text { explores other pathologies } \\
\text { with the same signs) }\end{array}$ & $\begin{array}{l}\text { Understand the } \\
\text { underlying physiology } \\
\text { of the body systems } \\
\text { and relate changes in } \\
\text { function to signs and } \\
\text { symptoms of } \\
\text { pathology; } \\
\text { consider alternate } \\
\text { pathologies producing } \\
\text { similar signs }\end{array}$ & $\begin{array}{l}\text {...you did visual field testing in Mrs } \\
\text { Gage, (ignoring the cataracts) what } \\
\text { would the defect look like (or what is it } \\
\text { called) and where have you seen this } \\
\text { defect before? }\end{array}$ \\
\hline $\begin{array}{l}\text { Cross-referencing } \\
\text { previous cases (where } \\
\text { else have you seen...?) }\end{array}$ & $\begin{array}{l}\text { Apply principles of } \\
\text { clinical reasoning to } \\
\text { understand a medical } \\
\text { situation completely } \\
\text { and thereby anticipate } \\
\text { consequences; } \\
\text { consider alternate } \\
\text { pathologies producing } \\
\text { similar signs }\end{array}$ & $\begin{array}{l}\text {... One of your "patients" from } \\
\text { Introduction to Science of Medicine last } \\
\text { year happened to be one of Dr Water's } \\
\text { patients today with similar signs and } \\
\text { symptoms to Mrs Davidson's; who is it } \\
\text { most likely to be? }\end{array}$ \\
\hline $\begin{array}{l}\text { Quizzing yourselves on } \\
\text { "normal" vs "abnormal" }\end{array}$ & $\begin{array}{l}\text { Contrast and be able to } \\
\text { recognise expected } \\
\text { physiological changes } \\
\text { accompanying } \\
\text { pregnancy, aging... } \\
\text { versus disease-related } \\
\text { changes }\end{array}$ & $\begin{array}{l}\text {... Donna Ramsay's blood pressure in } \\
\text { her medical records is typically } 118 / 75 \\
\text { and her haemoglobin is } 130 \mathrm{~g} / \mathrm{L} \text {; and } \\
\text { during pregnancy at } 20 \text { weeks: } \\
\text { - her blood pressure is } 100 / 66 \text { ? } \\
\text { - her blood pressure is } 140 / 90 \text { ? } \\
\text { - her haemoglobin is } 109 \mathrm{~g} / \mathrm{L} \text { ? }\end{array}$ \\
\hline \multicolumn{3}{|l|}{$\begin{array}{l}\text { Injecting a bit of fun and } \\
\text { levity }\end{array}$} \\
\hline $\begin{array}{l}\text { Learning about co- } \\
\text { morbidities }\end{array}$ & $\begin{array}{l}\text { Develop an } \\
\text { understanding of } \\
\text { morbidities for which } \\
\text { one pathology is a risk } \\
\text { factor or that often are } \\
\text { found clustered } \\
\text { together }\end{array}$ & $\begin{array}{l}\text {...Ms Angsta complains again about } \\
\text { "bowel disorders", as was noted in her } \\
\text { previous medical history (screen 4); } \\
\text { given all that is known now about the } \\
\text { patient, what is/are the specific bowel } \\
\text { complaint(s) likely to be and what is the } \\
\text { likely diagnosis? }\end{array}$ \\
\hline $\begin{array}{l}\text { Other/side effects of } \\
\text { treatments }\end{array}$ & $\begin{array}{l}\text { Understand the } \\
\text { iatrogenic causes of } \\
\text { some signs and } \\
\text { symptoms }\end{array}$ & $\begin{array}{l}\text {...in Screen } 2 \text { Maria added that she has } \\
\text { had severe asthma since childhood } \\
\text { [note: and is likely to have been on } \\
\text { chronic glucocorticoid treatment]? }\end{array}$ \\
\hline $\begin{array}{l}\text { Extending learning by } \\
\text { magnifying some aspect } \\
\text { (e.g. dose) or considering } \\
\text { an improbable, but } \\
\text { possible sequence of } \\
\text { events }\end{array}$ & $\begin{array}{l}\text { Clinical reasoning } \\
\text { learning objectives }\end{array}$ & $\begin{array}{l}\text {...on initial presentation in Emergency, } \\
\text { Samuel has the signs and symptoms de- } \\
\text { scribed, except he is drooling more than } \\
\text { coughing, and he is more comfortable } \\
\text { and better able to breath when leaning } \\
\text { forward; moreover, his parents are } \\
\text { particularly concerned because another } \\
\text { non-immunised child with whom } \\
\text { Samuel had been playing in the past few }\end{array}$ \\
\hline
\end{tabular}




\begin{tabular}{|c|c|c|}
\hline & & $\begin{array}{l}\text { days arrived in hospital with suspected } \\
\text { meningitis? }\end{array}$ \\
\hline $\begin{array}{l}\text { Spinning the category of } \\
\text { patient }(\rightarrow \text { aged, pregnant, } \\
\text { obese, HIV-positive, etc. })\end{array}$ & $\begin{array}{l}\text { Extended consideration } \\
\text { of numerous learning } \\
\text { objectives }\end{array}$ & $\begin{array}{l}\ldots \text { at the time of her initial presentation } \\
\text { Ms French were a } 19 \text {, rather than a } 65 \text {, } \\
\text { year old woman? What impact would } \\
\text { this have on the risk factors for stroke? }\end{array}$ \\
\hline $\begin{array}{l}\text { Considering alternate } \\
\text { environmental factors }\end{array}$ & & $\begin{array}{l}\text {..Justin was an apprentice } \\
\text { horticulturalist working in an organic } \\
\text { greenhouse with a faulty exhaust fan } \\
\text { and presented with similar symptoms } \\
\text { (confusion, headache, nausea) that } \\
\text { corresponded with his dusting the } \\
\text { greenhouse plants with insecticide } \\
\text { [rotenone], despite having normal blood } \\
\text { oxygen, oxyhaemoglobin and } \\
\text { carboxyhaemoglobin levels? }\end{array}$ \\
\hline $\begin{array}{l}\text { Further discussion of } \\
\text { public health, } \\
\text { epidemiologic, research, } \\
\text { social, ethical, legal etc. } \\
\text { issues }\end{array}$ & $\begin{array}{l}\text { Various learning } \\
\text { objectives relevant to } \\
\text { specific subjects }\end{array}$ & $\begin{array}{l}\text {..Mrs Davidson was } 25 \text { years old and } \\
\text { one of several, similarly aged patients to } \\
\text { present with the same symptoms/signs } \\
\text { and no apparent reason in the same area } \\
\text { over the past few months? }\end{array}$ \\
\hline $\begin{array}{l}\text { Learning some of the } \\
\text { more practical aspects of } \\
\text { medicine }\end{array}$ & & $\begin{array}{l}\text {...if Mr Drummond comes to the } \\
\text { surgery for an appointment in late } \\
\text { Summer or Autumn? [note: this patient } \\
\text { has a respiratory disorder and, if should } \\
\text { a doctor see him in late } \\
\text { Summer/Autumn, an opportunity should } \\
\text { be taken to provide immunization } \\
\text { against the flu] }\end{array}$ \\
\hline $\begin{array}{l}\text { Introducing/understanding } \\
\text { complications, when the } \\
\text { PBL case covers } \\
\text { "normal" }\end{array}$ & & $\begin{array}{l}\text {... Samuel and his mother go down to } \\
\text { Melbourne for a short holiday one } \\
\text { Spring and there is a thunderstorm? }\end{array}$ \\
\hline $\begin{array}{l}\text { An opportunity to derive } \\
\text { additional } \\
\text { diagnosis/diagnoses, } \\
\text { including rare and exotic } \\
\text { ones }\end{array}$ & & $\begin{array}{l}\text {...Mr Winters said he also lost hearing } \\
\text { about ten years ago only in one ear, } \\
\text { which came on over a period of a } \\
\text { couple of days and resolved itself over a } \\
\text { fortnight; there was no injury to the ear } \\
\text { or damage caused by loud noises; would } \\
\text { that also be indicative of presbycusis? }\end{array}$ \\
\hline
\end{tabular}

Moreover, What Ifs provide a good opportunity for students to think well beyond yes/no answers. The following reproduction is a very replete discussion that could potentially follow from a single What If. Full disclosure: this particular What If has never been added to any PBL case and the discussion outlined would be far in excess of that expected for any What If, with much of that discussion being beyond the scope of students' learning in pre-clinical medicine. Nevertheless, the following is provided to illustrate the nature and potential of What Ifs. This prototype What If was designed to accompany a case of cholera poisoning in an aid worker returning form a disaster zone abroad: 
What if...

....after one day the copious, watery diarrhoea gives way to less frequent and less voluminous loose stools, which contain blood, mucus and pus; the analysis of the stool sample (screen 17) is lost and the patient develops abdominal pain and a body temperature of $40^{\circ} \mathrm{C}$ ?

Discussion

1. The point of most What Ifs, this one included is not to leap immediately to an alternate diagnosis, as sexy as some students believe that to be, but rather to reengage in clinical reasoning.

2. Initial analysis: Now for the more prosaic process: the stools are still loose, and less voluminous and frequent.

a. But, now they contain blood. How can that be? The blood mixed with faeces usually indicates ulcerative erosion of blood vessels. Contrast this to a cholera infection where the bacterium is non-invasive and the diarrhoea is caused by toxin that is released and ultimately triggers intact cells to do what they ordinarily do, albeit converted to a constitutive mode and can't turn it off). Here we have to start considering damage to cells in the gut. How and in what circumstances might this happen?

b. How about the presence of mucus and pus? This raises considerations of inflammation, either with or without infection and provides a basis for the ulcerative bleeding. How and in what circumstances might inflammation develop that result in loose stools with blood, mucus and pus?

c. What does the fever indicate? If everything we have been discussing is related (and that would be the most parsimonious explanation), then the fever indicates a systemic manifestation of the inflammatory process.

d. Abdominal pain? This does not add much on its own because there are so many types and causes of abdominal pain and it is not infrequently associated with inflammation. It could be useful later in putting all the information together, but at this point its value (along with the fever) is in decreasing the likelihood of cholera as the (sole) problem.

3. Ordering of information: So, maybe now it is time to prioritise general causes of the picture as at screen 17 [refers to the original presentation] plus the new information and consider the whole picture.

a. Inflammation is almost certainly involved and this is a fairly strong inflammatory response.

b. What are the causes of inflammation in the gut? Infections have to be ranked highly, and then it becomes a matter of considering what is causing the infection. Alternatively, there could be neoplasm ulcerating adjacent structures to explain the bleeding and inflammation (and possible infection). Anything else? 
4. Initial hypotheses: So, the patient has been to a disaster site in Indonesia. She returns with diarrhoea and tachycardia and is not feeling good at all. The stools turn bloody with pus and mucus. She develops abdominal pain and fever. How to manage her? The iv fluid she gets in the PBL case is a good start

a. Now what? Assume that this is an infection and start antimicrobials? If you want to treat with antimicrobials, which antimicrobial should be used?

b. So, we get to the sexy part of this exercise. Diagnosis is the basis for treatment. So, once you are certain of the cause, you can choose from available treatments, if there are any. Here is where discussions of uncertainty come into play. How certain do you need to be or can you be before embarking on a particular treatment. What happened to the analysis of the stool sample(!)? If it is an infection then the microbe can be identified, and even better sensitivity-tested to take out all the uncertainty (or does it?).

5. New information prompting rethink: Another stool sample is sent for analysis. While awaiting the results, the patient's condition deteriorates and we feel compelled to add some treatment to the iv fluid. Shigella is arguably the most likely cause of the diarrhoea and is, in general, easily treated with antibiotics. In fact, had the patient required antibiotic treatment in the PBL case, she is likely to have been given ciprofloxacin, which is also standard treatment, if required, for shigella. What if the cause is another bacterium? Also consistent with all the information is typhoid fever, which is caused by salmonella. Again, there are antibiotics to which the strains causing typhoid are susceptible, but it's probably not wise to go ahead without some thorough stool analysis (uncertainty!). There are emerging strains of drug-resistant salmonella and Indonesia is a place where there are not only strains which are multidrug resistant to first line antibiotics, but there is also emerging resistance to ciprofloxacin. Then again, the infection might not be bacterial. There is a reasonable possibility that this is an Entamoeba infection. In that case, if antimicrobials were required, something like tinidazole or metronidazole would be required.

a. WAIT It could be a case of enterohaemorrhagic E coli, which is bacterial, so back to antibiotics like ciprofloxacin, right? Wrong. Antibiotics are contraindicated since they apparently increase the release of toxins, which are associated with haemolytic uraemic syndrome and we do not want the patient the patient to get worse.

b. MORE The presentation in the What If is written so that it is also consistent with severe ulcerative colitis, which is not an infectious disease at all. It is an inflammatory disease and therefore treated with anti-inflammatory drugs. Some of these, such as corticosteroids decrease the immune response and would therefore possibly exacerbate an infection, if the diagnosis is incorrect.

\section{What Ifs: real examples from two PBL cases}

What Ifs are usually provided as 3-4 per PBL case and the expectation is that the answers will be relatively short; much shorter than the prototype above. To illustrate, Table 2 below contains five typical What Ifs from three existing PBL cases, including the sort of answers we would expect of students. 
Table 2: Sample What Ifs

\begin{tabular}{|c|c|c|}
\hline $\begin{array}{l}\text { PBL case } \\
\text { study }\end{array}$ & What If... & Outcome \\
\hline $\begin{array}{l}\text { peptic } \\
\text { ulcer } \\
\text { disease }\end{array}$ & $\begin{array}{l}\text {...the patient states that her epigastric pain seems to come on after she } \\
\text { eats dinner, which is her one large meal of the day, and the Panadol did } \\
\text { not do much to relieve the pain. }\end{array}$ & Increases possibility of gallstones as cause. \\
\hline $\begin{array}{l}\text { thrombotic } \\
\text { stroke }\end{array}$ & $\begin{array}{l}\text {.. at the time of her initial presentation the patient was a 19, rather than } \\
\text { a } 65 \text {, year old woman? What impact would this have on the risk factors } \\
\text { for stroke? } \\
\text {.. on taking the patient's history each of the following elements were } \\
\text { separate, single additions; how would that alter the probability of an } \\
\text { ischaemic thromboembolic versus haemorrhagic stroke: } \\
\text { 1. If there was reason to suspect the patient was dehydrated? } \\
\text { 2. If the patient had nephrotic syndrome? } \\
\text { 3. If the patient had been in a boxing match the previous night? } \\
\text { 4. If that patient had a history of carotid stenosis? [ischaemic] } \\
\text { 5. If the patient had a history of untreated mitral stenosis? [ischaemic] } \\
\text { 6. If the patient had a mechanical heart valve? [ischaemic, unless she } \\
\text { was overdoing the accompanying anticoagulant medication } \rightarrow \\
\text { haemorrhagic] } \\
\text { 8. If the patient had a history of cancer (eg lung, kidney)?] } \\
\text { 9. If the patient has an atrial septal defect or patent foramen ovale? } \\
\text { taking warfarin, haemorrhagic] }\end{array}$ & $\begin{array}{l}\text { atherosclerotic and AF origins of thrombosis less } \\
\text { likely; other (usually less likely) factors become } \\
\text { more likely, eg coagulation disorders for thrombotic; } \\
\text { drug use and congenital vascular malformation for } \\
\text { haemorrhagic, patent foramen ovale } \pm \text { risk factors } \\
\text { for deep venous thrombosis for thromboembolic } \\
\text { stroke } \\
\text { 1. Ischaemic } \\
\text { 2. Ischaemic } \\
\text { 3. Haemorrhagic } \\
\text { 4. Ischaemic } \\
\text { 5. Ischaemic } \\
\text { 6. Haemorrhagic } \\
\text { 7. haemorrhagic; chemotherapy can also be } \\
\text { associated with increased coagulability } \rightarrow \\
\text { ischaemic } \\
\text { 9. ischaemic } \\
\text { 10. haemorrhagic } \\
\text { can increase her risk of also having cerebral } \\
\text { aneurysms }\end{array}$ \\
\hline
\end{tabular}




\begin{tabular}{|c|c|c|}
\hline & $\begin{array}{l}\text { 10. If the patient's father died at the age of } 30 \text { years following a bleed in } \\
\text { the brain? }\end{array}$ & \\
\hline $\begin{array}{l}\text { anxiety } \\
\text { disorders/ } \\
\text { substance } \\
\text { abuse/ } \\
\text { neck pain }\end{array}$ & $\begin{array}{l}\text {...the patient complains again about "bowel disorders", as was noted in } \\
\text { her previous medical history (screen 4); given all that is known now about } \\
\text { the patient, what is/are the specific bowel complaint(s) likely to be and what } \\
\text { is the likely diagnosis? }\end{array}$ & $\begin{array}{l}\text { abdominal pain and / or diarrhea and / or } \\
\text { constipation; irritable bowel syndrome a condition } \\
\text { frequently comorbid with generalized anxiety } \\
\text { disorder } \\
\text { the daughter is an adolescent, which means she has a } \\
\text { brain that is still developing and is in a much- } \\
\text { increased risk period for substance dependence. The } \\
\text { reasons include increased sensitivity of the brain to } \\
\text { the effects of drugs and underdevelopment cortical } \\
\text { regions necessary for exercising judgement. The } \\
\text { fact that she has been exposed situations with } \\
\text { alcohol and drug misuse in the home and has likely } \\
\text { had access to these substances increases the } \\
\text { vulnerability. }\end{array}$ \\
\hline
\end{tabular}




\section{Multi-directional symptoms PBL cases}

A variation on the conventional PBL case and What Ifs (and an exercise that was actually once described by one of the medical students as 'a What If on steroids') is the multi-directional symptoms case, hereinafter referred to simply as symptoms cases. The main differences between these and conventional PBL cases are:

- Symptoms cases are written to focus on the spectrum of different pathologies that are likely to cause a common symptom, such as abdominal pain, fever in a returning traveller, swelling of a limb after injury, waking up in the middle of the night, etc., the mechanisms of the symptom (and signs) and the process of relating signs to diagnoses. Thus, on the scale between content knowledge and application, the symptoms exercise is closer to the practice of clinical reasoning over learning about a certain single system or pathology.

- The narrative that extends from the initial presentation scenario is not a single linear continuation that provides additional information leading to an added dimension of a diagnosis and discussion of management. Rather, the initial presentation constitutes a core scenario, which begins the process, and multiple independent narratives, each leading to an unrelated diagnosis, follow. In this sense, the core represents a conventional starting point, with each of the independent narratives constituting the equivalent of a more fully developed What If. An example case is provided, and it will be left up to the reader to decide whether the case is a 'What If on steroids'.

The educational advantages of a multi-directional over a conventional PBL case relate to shifts on both the mode and depth of learning. The multiple scenarios themselves assume role of CBL facilitator in advancing the discussion. Whereas a facilitator would be expected to ask questions to prompt students to think laterally, the changes in the various follow-on scenarios virtually say, "let's take this line of reasoning through a different set of findings." Because of the timing of these cases in the medical course (late second year), students have already acquired much of the factual knowledge underpinning the clinical reasoning process and thus these exercises surmount conventional PBL. Accordingly, the focus shifts from being a vehicle for knowledge and comprehension to application and analysis. Thus, the multi-directional symptoms case act as a bridge in the transition to the more mature type of learning the students will engage in during clinical rotations and in advanced medical training.

In the present example case, an elderly woman is brought to the emergency department having fallen, hit her head, been momentarily unconscious and now exhibiting cognitive impairment. The initial assessment (core scenario) is consistent with any number of neurological and psychiatric causes of cognitive impairment, which students are expected to derive and consider how each would be evaluated. At that point, students get access to each of the independent follow-on narratives. Below are abridged versions of the core scenario and two of the followon narratives. Please note that these materials are delivered electronically to the students in a format whereby the information is parcelled out in sequence. Hence, the reference to screens, which represent the quantum of information presented to the students at one particular time. For interested readers, the full text of the PBL case is available from the author. 


\section{SYMPTOMS PBL CASE 2016: SASCHA MORPHEUS}

Begin Core Scenario:

\section{SCREEN 1}

You are a registrar in emergency medicine on a Saturday evening during the fifth day of unseasonably hot weather, when one woman called Rhea Titan, a nurse, accompanies another, more elderly, lady in a wheelchair for examination.

Ms Titan explains that the other woman is Mrs Sascha Morpheus and both have just come from a wedding reception, where Mrs Morpheus fell and struck her head. Ms Titan only met Mrs Morpheus today and relates the following story:

Mrs Morpheus had been dancing, lost her footing, fell forward and, despite a number of people coming to her aid, struck her forehead on the floor. Ms Titan was on another side of the room and hurried to the scene to offer assistance. By the time Ms Titan arrived, Ms Morpheus had lost consciousness, seemingly suffered a seizure and regained consciousness. Ms Titan does not know whether the loss of consciousness or seizure came first. In any event, Mrs Morpheus was unconscious for only a short time, a half minute or less. When Mrs Morpheus regained consciousness, Ms Titan asked for someone to ring an ambulance. Mrs Morpheus said no and then insisted that the episode was "really nothing" and adamantly refused to be taken by away by ambulance. At that point Ms Titan asked Mrs Morpheus where she was and what she did today, but Mrs Morpheus was unable to answer. Under the circumstances she agreed to travel to nearby hospital in the nurse's car. After checking to see that Mrs Morpheus's neck was not injured, Ms Titan drove her here.

\section{SCREEN 2}

[consists of an initial interview/history and physical examination of the patient. It establishes the presence of some limited cognitive deficits and apparent physical damage limited to a bruise and swelling on the forehead. Then...] You order a priority urgent $C T$ head and Mrs Morpheus is taken directly to imaging. Ms Titan is unable to provide any further information on Mrs Morpheus.

At that point you are told that another elderly lady, Mrs Hypnos has arrived in the waiting area inquiring about Mrs Morpheus. Mrs Hypnos is able to provide some background information.

\section{SCREEN 3}

\section{DISCUSSION QUESTIONS}

1. What is the key information here?

2. Explain the significance of each of the patient's signs in Emergency. Do they fit with any medical or psychiatric conditions? 
3. What is the rationale for ordering a CT?

4. How would Ms Titan have ascertained the likelihood of a neck injury to Mrs Morpheus?

5. What would you do now?

\section{SCREEN 4}

This exercise now consists of five separate scenarios (A-E) that follow on from the preceding initial presentation. Each scenario begins where the initial presentation left off and concludes approximately two hours after Mrs Morpheus returns to Emergency after her CT is done. The exercise is designed so that each of the scenarios is done to completion in succession.

Before starting the scenarios, record the following information:

\section{DIAGNOSTIC HYPOTHESES BASED ON PRESENTATION/HISTORY} OBTAINED IN EMERGENCY (note: your group may have more or fewer than four diagnostic hypotheses, but thinking of four represents a good start; similarly, not each hypothesis will necessarily require history, physical exam and investigations to test as outlined in the next three boxes)

$1-4$

\section{ADDITIONAL INFORMATION (HISTORY) REQUESTED TO TEST EACH} DIAGNOSTIC HYPOTHESIS

$1-4$ 


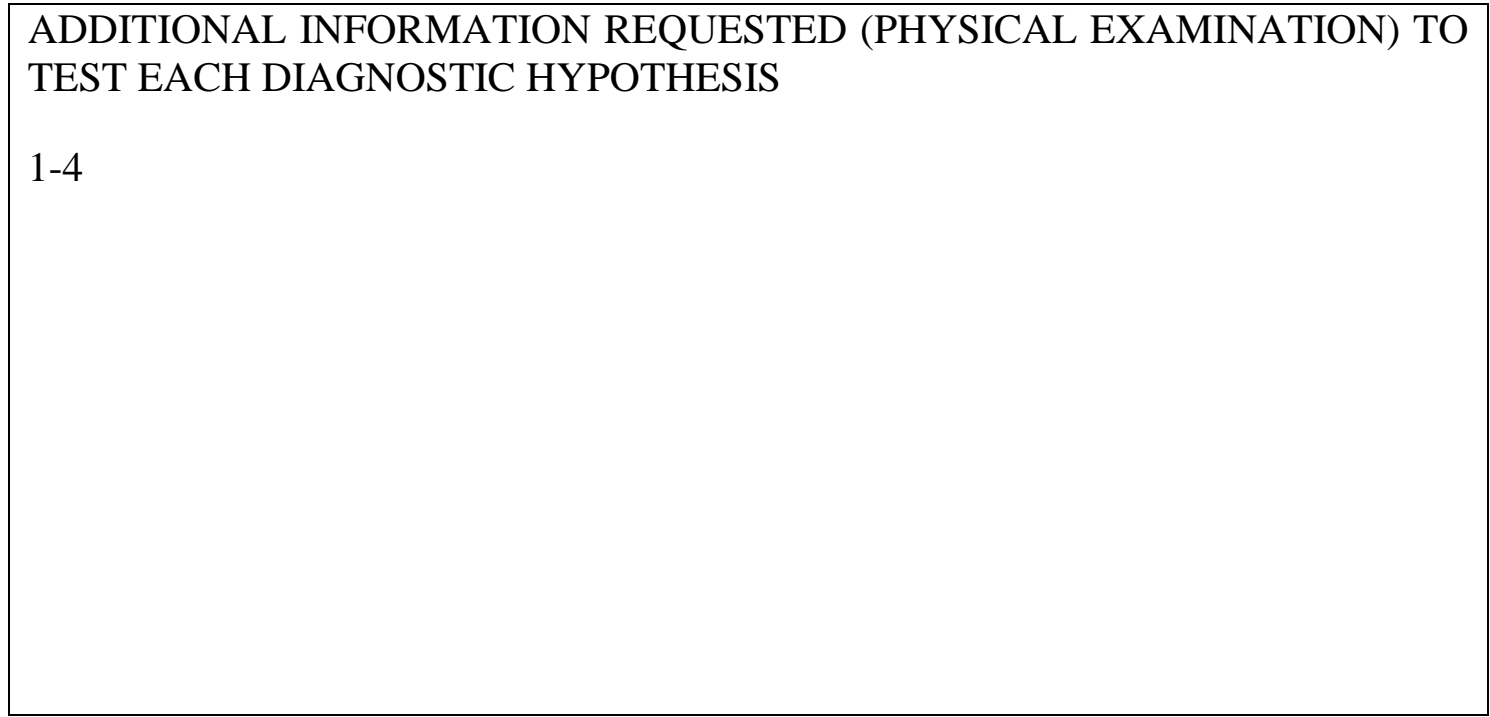

ADDITIONAL INFORMATION REQUESTED (INVESTIGATIONS/IMAGING) TO TEST EACH DIAGNOSTIC HYPOTHESIS

$1-4$

ONCE YOU HAVE COMPLETED RECORDING THIS INFORMATION, PROCEED TO THE NEXT SCREEN

End Core Scenario 


\section{Continuation (follow-on) scenarios}

In this particular PBL case there are five follow-on scenarios (A-E) all of which are consistent with the Core Scenario and various neurological and psychiatric conditions. The continuation scenarios for two of the five conditions, delirium (A) and concussion (D) are presented below.

Begin Independent Follow-on Scenario A

\section{SCREEN 5}

\section{Scenario A}

Additional history: Mrs Hypnos meets you in a consulting room, bringing Mrs Morpheus's handbag and hearing aids and glasses, which fell on the floor when Sascha fell. In response to questions about Mrs Morpheus's medical history, Mrs Hypnos provides the following information:

Mrs Hypnos is the grandmother of the bride whose wedding Mrs Morpheus had been attending. The two have known each other for over 50 years, with Mrs Hypnos having introduced Mrs Morpheus to her late husband (the two husbands were related to each other). Mrs Morpheus would be 70 years old. The adhesives factory refers the place where Mrs Morpheus worked until seven years ago. Sascha started work there and bought a house with no air conditioning within walking distance of the factory in 1970, where she still lives by herself. She has become increasingly unpredictable since quitting work at age 63. Her unmarried son was a contractor in Afghanistan when he died three years later. That event hit Mrs Morpheus particularly hard emotionally and, as a result, she began treatment with Zoloft (sertraline). When Sascha's husband died earlier this year she asked her GP for a stronger depression medication, which effectively stabilized her mood. Ordinarily, Sascha maintains contact with a small group of old friends and tries to have tea at the local club once or twice per week. She missed going to the club in the week prior to the wedding, telling her friends she was just feeling a bit off. Because Mrs Hypnos had invited Sascha to the wedding, she confided to Mrs Hypnos that this coincided with increased frequency and such pain while urinating that Sascha even cut back on drinking tea which was her beverage of choice. Mrs Hypnos says that she knows of no previous episodes of similar cognitive impairment in Mrs Morpheus, but she adds that Mrs Morpheus has been living alone since the death of her husband and they really do not see each other that often.

\section{DISCUSSION QUESTIONS}

1. What is the key information here?

2. Explain the significance of the elements in the additional history above. 
Screens 6-8 provide students with additional information that would be consistent with Mrs Morpheus suffering from delirium as a result of several factors. Each screen includes discussion questions to prompt students to outline their reasoning.

\section{SCREEN 9}

Before going on to the next scenario, record the following information:

$\begin{array}{lccccr}\underline{\text { DIAGNOSIS }} \text { BASED } & \text { ON } & \text { PRESENTATION/HISTORY } & \text { OBTAINED IN } \\ \text { EMERGENCY } & + \text { ADDITONAL } & \text { HISTORY } & \text { FROM } & \text { MRS } & \text { HYPNOS AND } \\ \text { KNOWLEDGE OF CURRENT MED + CT RESULTS AND SPEAKING WITH MRS } \\ \text { MORPHEUS ON RETURN } \text { FROM RADIOLOGY }+ \text { SUBSEQUENT } \\ \text { INVESTIGATIONS/EXAMINATIONS }\end{array}$

MANAGEMENT: PHARMACOLOGY

MANAGEMENT: MEDICAL/SURGICAL

MANAGEMENT: PSYCHIATRIC AND PSYCHOLOGICAL

MANAGEMENT: SOCIAL AND COMMUNITY

End Independent Follow-on Scenario A 
Begin Independent Follow-on Scenario D

SCREEN 20

\section{Scenario D}

Additional history: Mrs Hypnos meets you in a consulting room, bringing Mrs Morpheus's handbag and hearing aids and glasses, which fell on the floor when Sascha fell. In response to questions about Mrs Morpheus's medical history, Mrs Hypnos provides the following information:

Mrs Hypnos is the grandmother of the bride whose wedding Mrs Morpheus had been attending. The two have known each other for over 50 years, with Mrs Hypnos having introduced Mrs Morpheus to her late husband (the two husbands were related to each other). Mrs Morpheus would be 70 years old. The adhesives factory refers the place where Mrs Morpheus worked until seven years ago. Sascha started work there and bought a house with no air conditioning within walking distance of the factory in 1970, where she still lives by herself. She has become increasingly fond of outdoor and leisure activities since quitting work at age 63. Her unmarried son was a contractor in Afghanistan when he died three years later. That event hit Mrs Morpheus particularly hard emotionally and, as a result, she began treatment with Zoloft (sertraline). Sascha was similarly hard hit by the loss of her husband, but is adjusting to life without him. Ordinarily, Sascha is very reliable in maintains contact and activity with her friends and tries to have tea at the local club once or twice per week. She missed going to the club in the week prior to the wedding, telling her friends she was just feeling a bit off. Mrs Hypnos says that she knows of no previous episodes of similar cognitive impairment in Mrs Morpheus, but she adds that Mrs Morpheus has been living alone since the death of her husband and they really do not see each other that often. Mrs Hypnos did note that Mrs Morpheus was clearly enjoying herself at the wedding; so much so that she even saw her drink two glasses of wine, which is quite unusual for her.

\section{DISCUSSION QUESTIONS}

1. What is the key information here?

2. Explain the significance of the elements in the additional history above.

Screens 21-23 provide students with additional information that would be consistent with Mrs Morpheus temporarily suffering from the consequences of a mild concussion. Each screen includes discussion questions to prompt students to outline their reasoning. 


\section{SCREEN 24}

Before going on to the next scenario, record the following information:

\begin{tabular}{|lccccr|}
\hline DIAGNOSIS & BASED ON & PRESENTATION/HISTORY & OBTAINED IN \\
EMERGENCY & + ADDITONAL HISTORY FROM MRS & HYPNOS AND \\
KNOWLEDGE OF CURRENT MED + CT RESULTS AND SPEAKING WITH MRS \\
MORPHEUS ON RETURN FROM RADIOLOGY + & SUBSEQUENT \\
$\underline{\text { INVESTIGATIONS/EXAMINATIONS }}$ & & \\
\end{tabular}

MANAGEMENT: PHARMACOLOGY

MANAGEMENT: MEDICAL/SURGICAL

MANAGEMENT: PSYCHIATRIC AND PSYCHOLOGICAL

MANAGEMENT: SOCIAL AND COMMUNITY

End Independent Follow-on Scenario D

\section{Next step in the process}

In practice, the symptoms PBL case would be completed to this point (after Scenario E) by the students as a group, without facilitator, in their PBL rooms. Several days later, in a meet-withthe-consultant session (entire cohort in theatre) the whole case is reviewed, parsed, commented on and questions discussed. 


\section{Results/experience}

Neither What Ifs nor multi-directional symptoms PBL cases were created as research projects and, consequently, there was never any intent to measure their effectiveness systematically or quantitatively. What Ifs were first introduced in 2015 and have been part of the PBL program continuously since. Anecdotal evidence is that they were and continue to be well received by the students and that they are serving the core purpose, which is to extend students engagement with material as they complete each PBL case and stimulate thinking in many clinically related directions once they have been exposed to the basic foundation knowledge that they acquired by having done the PBL case.

Interestingly, 2015 was the only year that students made specific references to What Ifs in the University-conducted, student evaluations of course (SEC), and then it was only second year students (with the exception of one first-year student who complained about not being provided the "answers" every week). It is tempting to speculate that the reason for this relates to the fact that What Ifs were a novelty only for that particular cohort. First year students then and all students subsequently would have been exposed to What Ifs all along. The specific comments (total of 40-45 students completed the SEC) in 2015:

- The PBL model is generally interesting and the school has made some efforts to improve it (such as adding what if questions).

- If report back was discarded then there could be more time for things that actually test our knowledge such as the what ifs, the vignettes,

- "What ifs" provided in PBL were useful in applying content in a variety of clinical cases and prompting further study.

- [particularly good about the course] 4. 'What if's at end of PBL cases and the provision of answers to What If

- What ifs are great. Anatomy Museum is really useful. The lectures that were lecture captured were very useful for revision.

Non-anonymous feedback on What Ifs, whether offered directly by students or via their PBL facilitators, was universally positive. Non-anonymous feedback, as such, is almost always positive and, while good to hear, is nevertheless of limited utility.

More encouraging is evidence of ongoing engagement by students in discussion of What Ifs, such as the following received via email during the final week of the writing of this manuscript:

A what if today asked:

"What if...

...Ms Jones needs estrogenic treatment to prevent fractures when she has osteoporosis, should she resume her combination treatment; what about estradiol or ethinyl estradiol; what non-estrogen options are there?"

I was just wondering why she would not be on combination therapy seeing as though she still has a uterus? The answer was apparently that she should receive Raloxifene.

Kind regards, 
Students also demonstrate continued interest in every year's symptoms case. The specialists who preside over the meet-with-the-consultant session, such as the neuropsychiatrist who presided over the case included above, report abundant participation by students by both their presence and engagement in discussions. There has never been a problem finding a specialist willing to work on the drafting of these cases either.

Other staff are supportive of the program and often keen to provide What Ifs of their own for consideration. PBL facilitators are generally out of the discussions by the time What Ifs are introduced at the end of PBL cases (see Technological aspects, below), but report that they regularly remain in the room because of the satisfaction they derive from observing the students solving the What Ifs.

\section{Discussion/Summary}

Problem-based learning is a widely used mode of education. It may or may not remain a standard mode of medical education for much longer (Srinivasan 2007). Although it has numerous advantages over other modes of medical education, there are a number of areas where it is relatively weak and What Ifs and Symptoms cases represent relatively simple adjuncts to strengthen those areas. What Ifs are short, easy to write and can be rotated in and out, year by year, to provide novel dimensions to the cases without having to create entirely new cases or alter learning objectives. One key area where What Ifs confer an added advantage to conventional PBL is when they are used to introduce replacement information, retrospectively, at certain points in the PBL case to advance students clinical reasoning skills. In that regard, What Ifs can be thought of as representing a partial transition to CBL at the end of each PBL case. In addition, in our experience the students find What Ifs an enjoyable way to finish a PBL case and keep the whole process fresh.

The Symptoms PBL cases take this one step further. They provide multiple, related, albeit independent patient-cases within the set of narratives, require students to apply previously acquired clinical knowledge in a clinical reasoning process multiple times and include both peer-teaching (in the initial group session where the students go through the complete narrative) and consultant-teaching, involving guiding of discussions and asking questions of the students (in the subsequent meet-with-the-consultant session). In these regards, the Symptoms cases represent and even further transition to CBL (ten Cate 2018; McLean 2016; Srinivasan et al 2007), thereby providing the students with multi-faceted experiences.

\section{Technological aspects}

Although technological innovation was not a focus of the present work, the application of up to date IT systems is integral to the success of the novel learning material presented here. To derive the advantages of CBL in assisting students to acquire and hone their reasoning skills requires the recruitment of content experts who are active participants in the group discussion (ten Cate 2018; Srinivasan et al 2007), and even competent content experts are required to undergo training to become competent facilitators (Jones 2006). The current project made of the delivery of What Ifs and Symptoms cases by stepwise release of information electronically via an intranet. Thus, PBL facilitators, trained as they are to maintain discussion, did not have to be part of the process, because the release of the What Ifs meters the discussion; nor is there need for a content expert at the that time. Once the students have pondered the What Ifs, further discussion with a content expert can occur some time later during the "wrap" session for the respective PBL case. A similar sequence occurs with the symptoms PBL cases, which are done 
by the group in the absence of a facilitator and then followed up by the meet-with-theconsultant session, which is conducted by a content expert.

Future directions for this line of learning will make more use of technology. What Ifs can be aligned and cascaded. In such a system, depending on the response of each student to each What If, the release of the subsequent related What If would be determined and so on. Similarly, one plan for multi-directional symptoms cases would be to program the delivery of the follow-on scenarios in varying order to different PBL groups; then to require nominated students to "visit" other PBL groups at certain points in process. The aim behind this is to mimic realistic occurrences where learned expertise is shared in order to facilitate the best outcomes.

\section{Acknowledgments}

The author would like to express appreciation to many colleagues who have been involved in discussions of PBL and CBL and drafting of What Ifs and Symptoms cases; in particular Prof Harry McConnell and Associate Prof Andrew Teodorczuk for their assistance with and/or presentation as the consultant in the Symptoms case partially reproduced here, Ms Barbara Wallace and Dr Sujeevi Nawaratna for editorial assistance with Symptoms cases and What Ifs and Prof Ken Donald, who never fails to provoke thinking on potential improvements to medical education. I would also express gratitude to the hundreds of students at Griffith University medical school, who have endured exposure to many dozens of What Ifs, particularly those students who successfully suppressed their groans, and provided encouragement and comments for improving What Ifs.

\section{References}

Custers, E. J. F. M. (2018). Training clinical reasoning: Historical and theoretical background. In O ten Cate, E. J. F. M. Custers \& S. J. Durning (eds.), Principles and practice of case-based clinical reasoning education (pp. 21-33). Cham Switzerland: Springer Open

Jiménez-Saiz, R. \& Rosace, D. (2019). Is hybrid-PBL advancing teaching in biomedicine? A systematic review. BMC Medical Education, 19, 226-233

Jones RW (2206) Problem-based learning: description, advantages, disadvantages, scenarios and facilitation. Anaesthesia and Intensive Care, 34, 485-488.

McLean, J. (2016). Case-based learning and its application in medical and health care fields: a review of worldwide literature. Journal of Medical Education and Curricular Development, 3, 39-49

Shields, H. M. (2011). A medical teacher's manual for success. Baltimore: Johns Hopkins Press

Srinivasan, M., Wilkes, M., Stevenson, F., Nguyen, T. \& Slavin, S. (2007). Comparing problem-based learning with case-based learning: effects of a major curricular shift at two institutions. Academic Medicine, 82, 74-82

ten Cate, O. (2018). Introduction In O. ten Cate, E. J. F. M. Custers \& S. J. Durning (eds.), Principles and practice of case-based clinical reasoning education (pp. 3-19). Cham Switzerland: Springer Open

Thistlethwaite, J. E., Davies, D., Ekeocha, S., Kidd, J. M., MacDougall, C., Matthews, P., Purkis, J. \& Clay, D. (2102). The effectiveness of case-based learning in health professional education. A BEME systematic review: BEME guide no. 23 Medical Teacher 34:6, e412-e444 DOI: 10.3109/0142159X.2012.680939 